\title{
The Image of Historical Figures in Kazakh Literature
}

\author{
Meiramgul Kussainova and Zhanar Abdigapbarova
}

\begin{abstract}
Kazakh literature is rich for writers who wrote fiction about the famous historical figures. Each year, besides legends and folk tales which survived until nowadays a lot of fiction works are written. One of such world-famous historical legends is the legend about Chingis Khan and his descendant the last khan of Kazakh nation - Kenessary Khan. This paper offers a close analysis of the representation of Chinggis Khan in the Tarikhnama in unpublished dastan composed by the turn of the century Kazakh writer Shadi Zhangiruly.

The image of Kenesary Kasimov has been particularly highlighted in the second part of the paper. Kenesary Kasimov who had roots from the dynasty of Chingizidy was the last khan in the Kazakh steppe and the leader of the national liberation movement in the epic poem Nysambai zhirau "Kenesary Nauryzbai".
\end{abstract}

Index Terms-Historical figures, Kazakh literature, legends, zhirau.

\section{INTRODUCTION}

A nation's spirit is most clearly shown in its literature. Every rational person is aware that a nation survives when its language, rhetoric, literature survives. Therefore, large number of scholars attempted to build a literature by exploring the past.

Let's find an answer to this question. We will make sure that the literature or the culture of every nation develops in a tight connection with the history.

All scholarly subjects have direct links with history and cannot be understood outside the context of history. Literature is no exception to this. In whatever century it was composed, it will reflect the events and phenomenon of the time in which it was composed. Even if contemporary authors choose historical events as the subject of their compositions, their works are the fruit of the present. Even if the author uses the words and language of an earlier time, their ideas will be the ideas of today. The old is made new, perspectives unfamiliar to the reader are brought forward, old events examined with fresh eyes. Yet at the same time, it must be remembered that ideas are always already deeply rooted in history.

Kazakh literature is rich for writers who wrote fiction about the famous historical figures. Each year, besides legends and folk tales which survived until nowadays a lot of fiction works are written.

One of such world-famous historical legends is the legend about Chingis Khan and his descendant - the last khan of Kazakh nation - Kenessary Khan.

Manuscript received on November 15, 2014; revised on February 28 2015.

The authors are with the Nazarbayev university, Kazakhstan (e-mail: mkussainova@nu.edu.kz, zhabdigapar@nu.edu.kz).

\section{THE IMAGE OF CHINGIS KHAN IN KAZAKH LITERATURE}

In addition to Chinggis Khan's appearance in the legends and songs of oral literature, there has been a constant production of prose narratives: Abish Kekilbaev novel Tale of Khansha-Daria is based on oral legends and songs of Chinggis Khan's last days and death; Tursinkhan Zakenuly's historical novel Tears of the Grey Wolves tells of the fall of the Chinggissid era Naiman and Kerei confederations; Sayirbek Bakbergenov Börte, the wife of Chinggis Khan is a narrative of Chinggis Khan's final campaign; Mukhtar Shakhanov's poem "Otyrar and the Defeat of the Victors, or the Guilt of Chinggis Khan" tells of the conquest of the city of Otyrar; Iran-Gayip's play Comedy of Beasts dramatizes the conflicts between Chingiss Khan and his sons; Mukhtar Magauin's Chinggis Khan and his era is a historical narrative.

There are such works of Nysanbay Zhyrau as "Kenessary-Nauryzbay", of M.Auezov as "Khan Kene" and of Ilyias Esenberlin as "Kakhar" that describe the image of the last Khan of Kazakh nation. As we see, all these works that uphold different views take an important position in the history of Kazakh literature. The images of the historical characters are portrayed from different perspectives in these works.

These works and their diverse ideas and conceptions ought be considered among the treasures of Kazakh literature.

Chingiss Khan and literature: he was not an author, not a scholar, and not a character in a novel, but a great Kagan. In the second millennium, he brought all of Eurasia under his rule of law. Our question today is, is there a relationship between Chingiss Khan and Kazakh literature, and if there is, what is the nature of that relationship? In the process, we will come to a clearer understanding of how the relation between literature and history.

It is necessary to keep these principles in mind when examining the image of Chingiss Khan in literary sources. It is clear that some literary sources were created in the time in which the great Khan, with his transformative political policy, was alive. The tradition of singing a Madak zhyr (praise songs), for example, comes from antiquity.

In addition to this, there are works that were composed only after Chingiss Khan's death. A wealth of oral literary legends, tales, and songs about Chingiss Khan have been passed down from ancient times until the present. As the Kazakh people know that "there is no treasure greater than a people's collective memory," legends and tales have been transmitted orally from one generation to the next, changing form with each new age. Figures who hold the respect of society for their heroic qualities are always the subject of new compositions that reflect how the world view of a society has developed. Of course, it is not possible that one society would ever develop only one world view, and historical events and figures thus 
often become the subjects of multiple distinct evaluations. The theme of Chingiss Khan examined in this paper provides an example of this. Representations of Chingiss Khan can be found in both written and in oral literature, yet Kazakh literature does not by any means contain a single, unified, image of Chingiss Khan. Despite this variety, there has been little scholarly study of the topic.

This article will take as its central topic the early $20^{\text {th }}$ century writer and activist Shadi Zhangyruly's dastan "Tarikhnama". "...Such fiction works which started from the Kazakh epos and were transmitted to written literature are the main values which present the moral integrity of our nation" [1] said the famous scholar, Professor K. Abdessuly. One of such works considered as the literary legacy of our nation is the legend "Tarikhnama" by Shadi.

The Tarikhnama is distinguished from the bulk of Shadi's works in both its aesthetics and in its topical focus. The poem consists of a series of short narratives which that collectively form a historical chronicle. Each of these narratives, however, is self-contained, focusing on the description of specific episodes in the history of the Khanates. Although Shadi records Chinggis Khan's wars, he consistently presents the Khan as a just and generous figure, and he emphasize the Khan's respect for Islam.

Although Shadi's "Tarikhnama" dastan covers multiple historical periods, it can be divided into two major sections. While the first portion addresses Chinggis Khan, the second portion is devoted to Abylai Khan. The work was never published as a book and survived to the present day in the form of a handwritten manuscript. The date of composition is not shown. However, a book published in Tashkent in 1914, "The Tale of the Caliph Haroun Al-Rashid," includes a list of forthcoming works by Shadi. The "Tarikhnama" poem is on that list. Today, the written manuscript is preserved in the archives of the M. Auezov Institute of Arts and Literature.

The reason that the book was not published might be the influence of political situation of that period. It means that the subject of Chingis Khan was a prohibited one at Soviet time.

In regards to the materials Shadi drew upon in composing this work, the scholar Nemat Kelimbetov writes that: "If we examine the structure and content of the poem, it appears that Shadi was inspired by Abylgazy Bakhadyrkhan's book 'The Shezhire of the Turks.' In addition to this, if one reads the 'Tarikhanama' it is not difficult to discern that Shadi Zhangyruly was deeply familiar with such foundational works of historical scholarship as Mukhammed Yusef's eighteenth century 'Tarikh Mukimkhanii,' the first version of Nuridin Akhund Mullah Tarkhad's 'Tarikhi Rakhimii,' and Mynis Khorazimii and his nephew Muhammadriza Agakhii 'Firdabs-ya-iqbal"' [2].

It is important to consider the legend "Tarikhnama" separately, which describes the life and heroic deads of Chingis Khan. The reason is that this composition plays a big role in Kazakh literature from Shadi's point of view, as well as from the point of Kazakh literature of XX th century. "Tarikhnama" has different features among Shadi's other compositions in the context of subject and fiction during his epoch. Before analyzing "Tarikhnama" by Shadi it would be appropriate to give some information about the author. Shadi Zhanghiruly was born in 1855, in Sozak region of Southern
Kazakhstan, in a family of simple rural worker. He was educated by a religious server which was called "molda" at the age of ten. Shadi which started his humanity way went to Shayan madrasah and educated by Appakh Ishan, after that he attended to the lectures of professor Abdollah Sharip in Shymkent. At that time he studied Arabic, Persian languages intensively and was familiar with the works of famous Muslim writers. With the purpose to improve his writing skills he went to study in "Mib-Arab" madrasah in Bukhara which was best known among Muslim people. He familiarized himself with the main Islamic values and learned religious norms which became the basis of his further works. Shadi was accused of being "Molda" and driven out. He died on 12 September, 1933.

A. Konyratbaev provides the following information about the genealogy of Shadi's ancestry: "Shadi Zhangyruly (the real name Sultanbek) was a descendant of Abilay Khan as Shokhan was. "Arkhar battle-cry" one of Ablay's sons Waly, Waly's son was Chingis, and Chingis's son was Shokhan. Another son was Kassim. Kassim had five sons Essengeldy, Erzhan, Kudaimene, Kenessary, Nauryzbay. Shadi was a grandson of Essengeldy. His father was Zhangir. Kenessary and Nauryzbay were batyrs, and Esengeldy was a silver-tonged leader. Zangir was a son of Essengeldy. At the age of fifteen, Zhangyr was taken up by Kenessary and was treated as a brother. Zhangyr was the right hand of Kenessary and one of his brave soldiers. After death of Kenessary in 1847, Zhangyr married Kenessary's wife - lady Mauti, according to the levirate custom" [3]. Mother Mauti gave birth to Shadi.

The writer was from the aristocratic family, therefore the poem tells the following: he is from the family of Khan therefore I tell of his deals it is a duty of each son to inherit the fathers' helm [4].

The real talent of Shadi, his concern about the past lead to the fact that Shadi took a brave step and included the stories of Khan's life in his poems.

It should be mentioned that "tore is a social group in Kazakh society. The descendants of Chingis Khan were considered as tore. They were not a part of Kazakh clans, they belonged to separate society. Tore men considered themselves as aristocrats. Only tore could become a Khan" [5]. Shadi was a tore, therefore he is considered as the descendant of Chingis Khan.

"Tarikhnama" describes the completed events which are arranged in an independent way. However the poems are given in time order. Such plot is called a "chronicle event". Each part tells a different story. The sections of the poem include: "The genesis of the nation;" "The escape from the Mongol Khanate and the flight to Mount Arkikun;" "About the beginning of the Barsha tribe;" "The division of the Kazakhs into three hordes;" "History of the Mongol Khans;" "History of the birth of Chinggis Khan;" "Temujin's fight with Ong Khan of the Kereit tribe;" "Temujin sends an envoy to Ong Khan;" "Temujin becomes Khan;" "Chinggis Khan victory over the Naiman;" "The death of Jamukan;" "Chinggis's conquest of the Merkit people;" "Chinggis Khan's alliance with the Kyrgyz;" "In the footsteps of Kushlik and Tokta Bek;" "Chinggis Khan's defeat of the Chinese and 
Kara-Khitai heathens;" "The numbers of Chinggis Khan's wives and children;" "Chinggis Khan sends Muhammadulyash as envoy to Sultan Muhammad of Khorezm;" "Why Sultan Muhammad's gifts were refused;" "Chinggis Khan sets out on campaign for Bukhara;" "Ögedei and Chagatai take Otyrar;" "Jochi Khan travels to Jand;" "Alak Noyan and Saktabyka come to Panakent and Khojand;" "Chinggis Khan goes to Takhshab, Termez, and Balkh;" "Chinggis Khan sends soldiers after Sultan Muhammad;" "Chinggis Khan's battle with Sultan Jalal al-Din;" "Chinggis Khan sends his son Tolui to Khorasan;" "Tolui Khan's travel to Nishapur;" "Chinggis Khan's return to his own people,;" "The character of Chinggis Khan;" "Chinggis Khan's son Ögedei becomes Khan."

Shadi's own references make it clear that multiple historical sources were consulted during the composition of the poem. In the section entitled "The division of the Kazakhs into three hordes," Shadi writes "this is the tale of the first tribes, taken from the letters of Abylgazi," and thus makes it clear that he was familiar with Abylgazy's works [4]. In addition, reference is made to a book by an unknown author entitled "Ruzata Safa." In the section entitled "The history of Mongol Khans," Shadi relates details drawn from histories of the Mongols and of the Mongol Khans. In one verse, he identifies Chinggis Khan as a direct descendant of the renowned Budenzhyr.

Chinggis Khan came into the world then the tenth generation of Budenzhyr. A whisper in the mouths of the people Chinggis, born of rumor [4].

In addition to historical texts, Shadi made use of the extensive corpus of oral legends concerned with Chinggis Khan. In describing Chinggis Khan's birth, the poet writes how the Khan's violent future was foretold when he was born holding a fistful of blood:

Temujin came into the world with one fist clutched shut.

And when the midwife pried it open they saw his hand grasped clotted blood [4].

In the Secret History of the Mongols, it is written that "Hoelin Ujin gave birth to Chinggis Khan in Delyin Bultak, in the land of the Ong, at the time when Esykei Batyr had come with the Tatar captives Temujin-uki and Kori-Buka. When Chinggis khan was born, he held a clot of blood clutched like gaming bones in his right hand. As he was born when the Tatar Temujin arrived as a captive, he was given the name Temujin in accordance with custom" [6].

Chinggis Khan made himself Shah with his own strength in his time he did great deeds.

Khorasan, Iran, Turan, the Desht-i-Kipchak, Hindustan, and China knew his power [4].

Shadi sometimes presents Chinggis Khan as a warmonger and dictator and sometimes as a just ruler. In his section on Chinggi's Khan's conquest of Otyrar, shows that the war began due to the actions of the city's leader, the Ghayir-Khan, and of the Ghayir's overlord, the Khorezm Shah Sultan Muhammad. According to the poem, when a caravan of Mongol traders were received by the Ghayir-Khan, one of the traders knew the Khan's personal named and addressed him with it. The Khan was enraged by this and had all of them put to death:

The Patsha made it known his title was Ghayir, he killed every man in the caravan.

All who had come together were killed, their wealth put in the Patsha's treasury [4].

Chinggis Khan's anger at this deed caused him to initiate his famous campaign against Otyrar. According to an ancient and unbreakable law, an envoy from another nation could not be mistreated or killed. Sultan Muhammad, however, ordered Chinggis Khan's ambassador executed after the Khan had sent three requests that the Ghayir Khan be detained. This stoked Chinggis Khan's anger and led to open war. V.V. Bartold confirms this interpretation, writing that, "Sultan Muhammad failed to understand that his deeds would hasten an annihilating war" [7].

In the section entitled "Why Sultan Muhammad's gifts were returned," the poem presents the Khorezm Shah's own impiety as the reason behind the Muslim's defeat.

And one day drunk on wine, shouting came Sultan Muhammad.

The poem continues: The holy Sheikh Majid-Aladin Baghdadi. This night he killed and made a marty. Dawn came, the wine left him.

And he understood what his night's work had been. When Sultan Muhammad remembered what he had done, he was filled with regret and ordered a pot of gold sent to the Sufi Najim-Aladin Kabri with the words "pray for me and forgive me for my crime." The Sufi Najim-Aladin grew angry when he heard this and replied:

This I say: Majid Aladin's wereguild.

Can no more be paid with gold than with stones.

And with these words refused the gift. At that time, there were many such violations of Sharia. The accusations of Ghayir Khan were believed and the blameless traders and envoys of Chinggis Khan were executed.

Because of this good fortune abandoned the Muslims

Their soldiers lined in battle against Chinggis.

No matter how many they outnumbered the Mongols

Defeated they fled the field of battle.

In the dastan, each of the military campaigns of Chinggis Khan and of his sons is depicted in turn. In connection with this, it is related how Chinggis Khan respected the religion and traditions of the people he had conquered. In particular, he was deeply respectful of the Islamic faith. When Chinggis Khan came to Bukhara, he spoke with the religious scholar Ghazy Ashiraf.

And Chinggis spoke to them: you are Muslims. What then must Muslims do?

Then they told that all humans are the creations of the only God.

There is one God. He neither begets nor is born, nor is there to Him any equivalent.

Chinggis said: "You are right, I know these words as well. What are the other orders of God apart from these?"

They then told Chinggis that the prophet Muhammad was the ambassador and servant of Allah, and Shadi writes that:

These words are true, Chinggis told them, in my own soul there is no doubt [4].

The Khan then enquired, 'what other commands does the Almighty have?' The members of the Ulama replied that Muslims should read Namaz five times each day, they should fast for one month each year, they should give a portion of 
their flocks each year as a religious tithe, and if possible they should go on Hajj once during their life.

When Chinggis heard this he was struck with wonder from these words he understood.

In all the world there is but one God with the power of creation.

Saying this, Chinggis gave the Ulama gifts and asks if they had any petitions they would make of him. The members of the Ulama requested in reply that the people of Bukhara be free of the obligation to pay taxes. Chinggis Khan accepted this petition, and degreed Bukhara be free of taxes. With this, Chinggis Khan displayed additional evidence of the justice and fairness that sprang from the strength of his belief in God.

As was noted above, the poem incorporated not only historical material but also the legends and folk-narratives of the Kazakh people. The poem provides a powerful version of the legend of how Chinggis Khan was told of the death of his first son Jochi. The Khan had degreed that "whoever tells me that Jochi has died, I will cut their tongue out and pour lead in their mouth.' One zhirau then took upon himself the duty and risk of informing the Khan of his son's death and went Chinggis. The zhirau said:

If the sea rages, who could calm it, oh my Khan?

If the poplar falls, who could set it straight, oh my Khan? [4]

Chinggis Khan then raised his head:

If the sea rages, my son Jochi would calm it, if the poplar fell, my son Jochi would set it straight.

Has this sorrow come to me, will my tears now run?

Has Jochi died, is this a song of sorrow? [4] The zhirau then sang to Chinggis Khan: I did not speak, you spoke, oh my Khan, your own punishment on your own head, oh my khan [4].

According to oral legend, the zhirau who told Chinggis Khan of his son's death was called Ket-Bygha, and Shadi writes: "In the legends of our ancestors it is said that the great zhirau Ket-Bygha from the Naiman clans in this way told the great and fearsome Khan about the death of his beloved son Jochi" [8].

Chinggis Khan was concerned for the well being of his people, and told his sons that they must always stand united so that the Kaganate he had made would not be shaken.

When I am gone may one of you be a leader, and may all of you acknowledge his degrees. No one then could stand in enmity to you. All will fall beneath the power of your hands.

Chinggis Khan had known when he himself was close to death, and selected his third son, Ögodei, as heir to his throne. The scholar Z. Qinaiatuly writes that, "When Chinggis Khan was breathing his last, he called for his sons Ögodei and Tolui and told them, "my time of death has come. With God's strength I have left for you a mighty empire, one it would take full year to ride from border to border. Lest the empire I have made for you not fall, strike at your enemies as though you were one person, show mercy to your friends. And one person only may hold my throne. As we have said before, that heir shall be Ögedei" [9].

My third son Ögedei is Khan, I have made him khan, set him in my place. With all your souls, follow him in unity abide by his orders [4] and in this manner, the great historical figure Temujin died.
Shadi gives a vivid picture of Chinggis Khan's physical appearance:

Everything about his body was pure,

His chest wider than anyone's, his might shoulders, a fierce face, a broad brow, a beard that flowed to his chest [4].

Shadi further depicts him as an active and heroic figure, one who on the battlefield stood with the first divisions, who trusted to his own opinion and was not swayed by other's words, whose anger cooled swiftly, who accepted alliances when offered but did not hesitate to fight when met with enmity, but who never killed scholars or artists, rather bringing them back to his own people so that they could serve as teachers.

Shadi emphasized Chinggis Khan's generosity with the following lines:

More generous than anyone, no one who came before him left empty handed [4].

And he presents Chinggis Khan as an adherent of Islam in these lines:

Though he would not leave his own religion, he gave great respect to Islam of those he kept close by his side, it is said the greatest number were Muslim [4].

In his historical poem, Shadi revealed himself as a writer whose concern with history took the form of a bold and beautifully written composition. The Tarikh-nama is valuable both for the wealth of historical details it incorporates and for the beauty of its prose. The author's fundamental goal in composing the work was both to increase his readers' knowledge of the history of the Khans and to create a new and vital account of that history. As he was himself a descendant of the Khans, he was concerned that if he did not write about their then partially forgotten history, no one would, and he took strength from the belief that his composition was a kind of filial duty.

In conclusion, it can be said that regardless of which Kazakh literary genre one reads, it is impossible not to encounter representations of Chinggis Khan. Understanding the close links and mutual development of history and literature remains a central task of scholarship.

\section{THE IMAGE OF KENESSARY KASSYMULY IN KAZAKH LITERATURE}

A figure that was widely studied in Kazakh literature is Kenessary Kasymuly. Kazakh governmental system of 13-19 centuries was under the control of Chingis Khan`s family. Strengthening of the Russian Empire system weakened the power of Chingis Khan's governing and incepted the governance of Russian general governors. The last governor of Kazakh nation among Chingis Khan's descendants was Kenessary Kasimuly (1802-1847). Kenessary Kasimuly was a historical figure who started the national liberation struggle.

The image of Kenessary found its place in works of Kazakh literature. Especially he is the most frequent mentioned historical figure in the rich heritage of Kazakh nation - the oral compositions of Kazakh literature. It is impossible to cover all literature compositions dedicated to Kenessary in a framework of one article. Therefore, the image of the historical figure will be analyzed by investigating the poem "Kenessary-Nauryzbay". 
Kazakhs are the nation with a rich historical background and culture, and deeply rooted traditions of describing and keeping them. Thoughts about the native land, memory of the heroes who fought for the independence of the land are handed down from one generation to another and kept in oral-historical works of the Kazakh people. This priceless heritage which represents a literary chronicle created on the basis of oral creative works, are thriftily used and kept by people, and passed on by word of mouth from generation to generation needs a thorough investigation.

It is impossible to define the quantity of legends and stories based on real historical events and processes. An unofficial history of the nation is kept on shelves of archives and libraries. There is no need to prove the fact that the majority of the oral and historical pieces are not collected and fixed yet.

Unfortunately, this richest treasure-house, the content of which evokes admiration of not only our scientists, but of the foreign ones as well, has never been studied from historical point of view. At present, when the scientific centers of Europe and Africa are actively working out methods and methodology of investigating oral-historical traditions, the local historical science does not spend much time to a thorough research of the very problem. There is no doubt that the systematic study of the best samples of the national tradition of oral history telling will considerably widen the horizons of the literature knowledge.

Thoughts about the native land, memory of the heroes who fought for the independence of the land are handed down from one generation to another and kept in oral-historical works of the Kazakh people. This priceless heritage which represents a literary chronicle created on the basis of oral creative works, are thriftily used and kept by people, and passed on by word of mouth from generation to generation needs a thorough investigation. These works, no doubt, are not an exact copy of historical events, but they reflect the idea of the nation about the epoch and their assessment of the social and political processes. We will try to explore the only genre of oral literature - historical epic.

Kazakh historical epic. The encyclopedia of Kazakh literature of the historical epic gives the following definition: "Historical epic - is an epic work which has been produced due to the specific historic event. All these epics are based on specific historic events, where main characters are people who took part in these events" [10]. The estimated amount of historic epics, which is systemized and collected in the Fund of Central Scientific Library of the Republic of Kazakhstan and Manuscript Department of Literature and Arts Institute after M. Auezov is 150; 600 if manuscripts and original copies included.

Peculiarities of historical epics. In the process of investigation the following peculiarities of historic epics - the largest branch of oral history were outlined:

1) Ideological peculiarity. The ambitions of people take most description rather than the description of tribes' related interests.

2) Feature peculiarity. The compositions which take place in heroic epics such as prediction, to look for a spouse, to woo, to have a heir or successor do not take place in historic epics.

3) Subjectivity. The subjective evaluation mixed with an author's direct perception of events takes place of an objective epos description mood that is peculiar to historic epics.

4) Linguistic peculiarity. Poetic, psychological parallelism and exaggerating dominate in heroic epics, whereas in historical epic there few examples of poetics and most of them have no psychological parallelism at all.

5) Condition of variance. By the way getting acquainted with several versions of the epic we have an opportunity to realize how rich our nation's folklore is and it shows how deep the imagination of nation is.

To sum up the historical epics are the epic works appeared due to the definite historic event. The historic accuracy may not be kept in historical epics, each period's historic-social, political state is described in artistic concluded way.

Now we should concentrate on the historical epics around nineteenth century. This is a period of peek of development in the history of historical epics. The heroes of national liberation struggle of nineteenth century Kenesary, Nauryzbai, Agybai, Zhankozha, Beket, Dossan, Isatai, Makhambet, Arkalyk and others are the main characters of historical epics. One of the peculiarities of these epics is the fact that they appeared almost half a century after the death of national heroes who became the main characters of epics. The reason is the frequent struggle against Russian and Kokand invasion in Kazakh steppes. In this emancipation movement people showed incredible courage, and it caused the necessity to glorify their bravery. That is why after each struggle new tales, stories, poems were created. During this century all spheres of life differed from earlier times and developed rapidly; the nation's creativity was also rapidly developing and followed the current events.

The historical epics of nineteenth century are classified into three kinds in terms of form:

1) The historical epics appeared due to the definite historic events. They are epics about the struggles ruled by Kenesary and Nauryzbai, Isatai and Makhanbet, Zhankozha, Dossan and Beket.

2) The historical epics created in traditional epos form. Kenesary - Nauryzbai, Dossan Batyr, The Bravery of Seventeen-year-old Zhakozha epics belong to this kind.

3) The historical epics created in the form of customs and traditions poems. Kuder kozha's Farewell with Karkaraly, Doskozha's farewell with homeland, and epics created in the way of mourn and consolation belong to this classification.

In one article to review all historical figures are not available, we decided to analyze poemotu image Kenesary Kasymova Nysambay zhyrau in the poem Kenesary Nauryzbai. The historical poem Kenesary - Nauryzbai Nysambai-zhirau is a valuable source for the study of the socio-political history of the Kazakhs in the first half of the $19^{\text {th }}$ century, and especially, for the study of the Kazakh revolt led by Kenesary Kasimov from 1837-1847. One of the notable aspects of the poem is the many versions of it in circulation after the rebellion.

\section{A. Nysambay Zhyrau}

Let's find out by term zhyrau and who was Nysambay zhyrau? The encyclopedia "Kazakh literature" gives the 
following definition of the term zhyrau - a prominent representative of the Kazakh oral-poetic genre; a steppe poet; composers and performers of epic works (songs, poems, epics, laments, etc.) [10].

Nysambai Zhamankululy was born in 1822 in the Syr-Darya region and died in a place called Ak-Koshar in what is now Zhalash Raion or Kyzylorda Oblast in 1883 . He was a poet, zhirau and ideologue of Kenesary Kasymov's movement (1837-1847). In the poem Kenesary-Nauryzbai Nysambai zhirau relates the following of himself:

They call me Nysambai, I was of the Ashamaily Kereit lineage, not being at all like my parents, I occupied myself with the craft of words, when I was 15 years of age. I joined the camp of Kenesary and Nauryzbai [11].

\section{B. Kenesary Kassymov}

The main character of the "Kenessary-Nauryzbay" poem by Nysambay is Kenessary Kassymov (1802-1847). He was the last Chingisid governor in the Kazakh steppes. His grandfather Abylay Khan ruled in Kazakhstan in the second half of $18^{\text {th }}$ century, having stood up to Jungar aggression and strengthened Kazakh nationhood. As a result of reformation policy, the khan power was eliminated in the beginning of $19^{\text {th }}$ century ("Khan" - the title of the ruler of the Kazakhs). Kenessary's father Kassym and brothers Sarzhan and Essengeldi headed widespread discontent against the Russian reforms and were killed. In 1837 Kenesary led national liberation movement of Kazakhs against the colonial policy of Russia in the Kazakh steppe. The uprising first emerged in northern Kazakhstan near Kokshetau, but then the movement spread on the whole of Kazakhstan. For 10 years he had led the liberation struggle against the policy of Russia, Bukhara and Kokand khanates. In 1841 the main Kazakh tribes elected him to be the khan; he was the last Khan in the Kazakh steppe. He died at the age of 45 during the battle with Kyrgyzs.

The folklore is rich in written and oral pieces dedicated to Kenessary. This article is aimed at analyzing Kenessary Kassymov's image in oral pieces, particularly in Kenessary-Nauryzbay poem by Nysambay. Nauryzbai was Kenesary's younger brother, who also participated in the liberation movements of the Kazakhs and is known for his heroism and courage.

\section{Condition of Variance}

The Poem Kenesary-Nauryzbai currently collected In the Collection of Central Scientific Library of the Republic of Kazakhstan and in the Manuscript Department of the M. Auezov Literature and Arts Institute. We have a few versions of epic by Nysanbai zhyrau Kenesary - Nauryzbai:

1) In 1903 Zhussipbek Shaichuislamov published it as Kissa Kene khan and Nauryzbai in Kazan.

2) In 1924 another version of Nysanbai's epic was published in Moscow under the edition of Zhussipbek Basygarin.

3) In 1938 the third version was published in Torgai based on the narration of Kashkynbai Karayev.

4) We can consider the Russian translation of Kenesary Nuryzbai by Nysanbai made by Zhantorin published in a few issues of "Orenburgskiy Listok" as the fourth version [12].
The oral historical works have one common feature; it is their heterogeneity regarding historical quality, especially the fact that they were recited many centuries ago by going the round; it also should be stated that the narrators added their own applications to the epics. Apart from this the author and the narrator altered the epic according to their political and class views. That is why it is of great importance to know the author and narrator in the process of analyzing historical epics.

We can conclude the interrelation and value of multi-version epics by the inference of Mukhtar Auezov: There might be a few persons' information about one particular event. This information should not be regarded as the same information about one tradition. Because one author may give wrong interpretation or give incomplete information whereas another one may give complete information. If there are two guesses about one definite historical event, and when two versions are compared and the difference is remarkable, it means it is about testimonial type. The second version may give the new information and complete the first version or on the contrary misrepresent the truth in the first version[13].

\section{Ideological Peculiarity}

In this study, we analyzed variants of the Nysanbai zhyrau's epic Kenesary - Nauryzbai. For instance, it can be said that Nysanbai zhyrau's epic Kenesary - Nauryzbai was severely misrepresented in the in Zhussipbek Basygarin's written work. Zh. Basygarin's version took completely different direction by the way of describing Nysanbai zhyrau's state of deploring heroes and changing his words with abusing ones. We can understand it from the following excerpt:

All of them robbers - murderers.

Stretched the truth and followed him like thieves [11].

The scientist Y. Bekmakhanov claims: Zh. Basygarin connects the misrepresentation of Nysanbay with himself. Because Zh. Basygarin's Grandfather Altybai Kobekov was the leader of Zhappas tribe and was killed by the rebels fsince he took part in the tsar troops which chased Kenesary [14].

Apart from this according to the archive sources the rebels destroyed his second grandfather Zhagabyl Tolegen's village several times. That is why these circumstances made $\mathrm{Zh}$. Basygarin opposite Nysanbai to the leader of the rebels".

As it was said previously some of the facts in Kazakh historical epics were misrepresented by narrators on purpose. For instance, in the epic Kenesary's war against Kyrgyz is said about Kenesary's murder of one of the Kyrgyz rulers. The truth we know is that Kenesary did not kill any Kyrgyz ruler. The narrators might have used such trick to describe Kene khan's bravery. That is why it is essential to analyze critically both written sources and oral ones; distinguish falsification from truth and to know the interests of narrators.

We can come across several historical epics created by the special task of the ruling class. For instance, we can see the elements of appraisal of Russian colonization from the following excerpt:

Our tsar, the great emperor sits on his throne, any tsar is on the side of his nation.

We do not care about peace and welfare, since our great emperor takes care of his people [11]. 
The researcher's important duty is not only separate truth form imagination and check them thoroughly but also to compare the facts found in the oral works with the scientific research from archives and museums.

In the process of investigating the social-political condition of Kazakh society in the nineteenth century the historical epics about Kenesary who encouraged people to fight against tsar's power and local ruler's oppression were used as the main source.

\section{E. Epic Tradition}

National epics described Kenesary as the people of great power. For instance, the following lines show that Kenesary frightened the tsar:

Only two words he says:

The first is the iron image makes a noise, the second is the red burning coal becomes a fire [11].

It is obvious how we should treat such kind of exaggeration which occurs in most of the oral historical epics. However it is a big mistake no to take them into consideration thinking that they are not worth of investigating. Because besides fairy tale personages the historic events based on truth are also described in such epics. For instance, the exact description of the enemy struggled against by rebellions is given, it is not only tsar's people who oppressed Kazakh nation but also its local rulers.

The rich sold Kazakh's liberty, the rich became friends with general, turned to enemies having received gifts from tsar [11].

In Nauryzbai Batyr's Killing of Tiger Nauryzbai batyr is described as a person of incredible power who killed the tiger.

Despite the cannon projectiles, they hit back and returned - by killing the ones who fired [15].

\section{F. Historical Truth in the Poem Kenesary - Nauryzbai}

The work are considered to be main sources about the society's state in the nineteenth century especially Kazakh nation's history of liberty struggle. The reason is the fact that these works are based on the events of that struggle. In scientific literature it is almost impossible to find the facts about remarkable fights and people who took part in the struggles. That is why it possible to find historical facts from these historical epics. Moreover these works help us analyze Kazakh-Russian interrelations in the nineteenth century. We can see the fair evaluation of statesmen made by people which was misrepresented in Russian manuscripts.

In Nysanbai's epic Kenesary Kassymuly's liberty movement is covered in all aspects. The narrator managed not only to describe bravery of Kenesary and Nuryzbai in traditional epic way but also to show the events which oppressed people:

In the times of khan Kene, we were worth like old camels,

We were like heavy snow. Giving names "Abylai" We passed ahead the enemies, when Kene khan were killed, we separated in different ways [11].

It is not only an epic but also a historic truth. In his epic Nysanbai gives information about Kazakh society's inner conflicts; Kenesary's main reasons of struggle and his fellow fighters; Kenesary's struggle against Kyrgyz rulers; it also gives information about important historical events even the facts about Kene khan's murder.

\section{G. A Brief Overview of Oral Metrialov Kenesary}

Doskozha's Farewell epic and Kuderi Kozha's Farewell with the Mount Karkaraly play a great role in the process of investigating the main reasons of people's movement against Russian colonization and local ruler's oppression. They are farewell epics which became the reason to fight and show the nation' sorrow in departing from the most beautiful places of Kazakh steppe Kokshetau and Karkaraly

The epic Nuryzbai - Khanshayim written by unknown author plays an important role regarding the topic of investigation. It gives the description of an event which took place in history that is Nuryzbai's campaign to Tleukabaks village. Kenesary's letter to Tleukabak is also saved in archive sources.

Kokbai akyn's Kenesary - Nauryzbai and Abylai Kenesary epics describe remarkable historic events starting from Abylai to Kenesary combining annalistic facts. It seems that Kokbai akyn collected all the heard information in epics.

In Kenesary, Kenesary, Sarzhan, epics Kenesary's surroundings and his fight against Russian colonization in Sary- Arka region are described. Both epics have historical features; however there are some fairy tale elements. The proof is Kenesary's killing of dragon who swallowed the crowd of people.

The oral historical epics About Kenesary and Nauryzbai's War, Kenesary and Nuryzbai's Taking of the Town Adyrly-Baitak, Spoiled Kazakh, Kenesary's Strike, Shortanbai Akyn's Words to Kenesary play a great role in the process of investigating the reasons of liberty movement started by Kenesary Kassymuly.

For the first time in our research work we offer it to the scientific circulation. From these epics we can see Kazakh people's hard times in agricultural and social lives caused by Russian colonization policy. In the process of investigation oral materials they were thoroughly compared with archive materials.

We can see the inner conflicts of Kazakh society in nineteenth century in the work Zhasauyl's Destruction. The epic gives information about the fact of murder of 90 soldiers of Nauryzbai when they were collecting zekat from Zhappas tribe in 1844 . The place where soldiers were buried called "Zhasauyl Destruction". The facts described in the epic are proved by the letter written by the sultan Akhmet Zhangorin to Orenburg Border Commission. The document gives information about how Nauryzbai's soldiers were killed and what Zhappas tribe thinks about this occasion.

We can consider the epic Sarzhan Batyr which describes Sarzhan who did not obey Russian colonization policy and fought against it in nineteenth century. The epic also describes the bravery of Kenesary and Nauryzbai besides Sarzhan's bravery. However there are some historical mismatches in the epic. For instance, the facts that Sarzhan is described as a younger brother of Kenesary, although he is Kenesary's elder brother and that Kenesary founded his khanate in times of Sarzhan. Kenesary was not a khan in period of Sarzhan and the name of Kenesary was unknown in that time [16].

We gave a brief summary to the oral heritage of nineteenth century. Despite the fact that these works possess different 
information and creative value, each of them gives the atmosphere of that exact period, represents the chronological order and describes the lives of historic personalities and shows their active work. The definite historic facts are closely connected with their biographies. These epics describe Kenesary bravery and their extraordinary adventures.

In the process of research most of the epics were dedicated to historic personality of Kenesary Kasymuly. One of the features of oral history is the fact that it has never contradicted to nation's interests by glorifying people who were the nation's enemy. The nation always brought shame on people like this. That is why we can say that the oral historical epics about Kenesary appeared because Kenesary fearlessly served to his nation. These works are about Kenesary's courageous war which lasted for ten years and about Kazakh nations struggle against outer enemies. Kenesary's movement is Kazakh nation's most glorious events in Kazakh history of nineteenth century.

Analysis of Kenesary Khan's personality from historical point of view has not been investigated completely yet. In Soviet period the name of Kenesary was misrepresented by improper conceptions such as "hypocritical brigand" and "insidious rebel". Whereas in works delivered by Kazakh nation's oral tradition Kenesary is described as a talented commander, a khan who concerned about the welfare of his nation, a competent diplomat. The fact that he is glorified in various aspects shows the nations fair evaluation.

By analyzing and classifying information in oral historical epics we can see that Kenesary's historical personality was represented in various ways:

- Kenesary is a heir of great Kazakh rulers Abylai and Kasym;

- Kenesary is a leader of liberty movement;

- Kenesary is a talented military commander;

- Kenesary is a khan who thought about his nation;

- Kenesary is a spiritual leader, benevolent sage, intelligent;

- Kenesary is just, orator;

- Kenesary is noble, generous man;

- Kenesary is a soothsayer, clairvoyant.

So we can see that Kenesary's image is categorized in the historical epics. Khan Kene's way of being the nation's courageous son is special. He is the one who served and cared about his nation. He was the one who raised the banner of existence, unity and liberty of his nation at hard times. That is why Kenesary's bravery is a special bravery. Heroes like Kenesary who fought for independence will live in nation's history forever. It is what oral history tradition states [17].

To sum up the development of oral history in nineteenth century is closely related to the historic-social condition at that period of time. Therefore their main content is concentrated on tsarist Russia and liberty heroes who fought against colonization policy of khanates in Central Asia.

The high level of oral history in nomadic Kazakh community is distinguished not only by its historical works which form its cognition but also by its aim to satisfy its aesthetic demand. Eventually in the process of research it was proved that Kazakh nation's oral history works in particular historical epics might be used as one of the sources to investigate Kazakh nation's literature and history.

\section{CONCLUSION}

In this article we will focus attention on the world-famous images of Genghis Khan's personality and his grandson Kenesary Khan in art works of Kazakh literature and comprehensively analyzed the image of the hero. Genghis Khan has a special role in Kazakh history. His invasion to the city of Otrar was the motive of many legends, stories and poetry. Undoubtedly, each author was trying to reveal the image of Hagan from different sides. Any writer evaluates the image of the well-known historical figure in the literature in the context of the social consciousness of his time. For example, one person finds different images in various works written from different points of view and is ahead from one generation to another. And our hero in the literature formed such. Each author writes on the basis of their worldview. And has been written. Formed in this society are two different points of view about Genghis Khan is the result of these transformations. Who praises, and who slanders. Our job is not to judge, but only Genghis Khan's review of the way in the work. Analyzing the works of Kazakh literature written in different periods, taking as a basis written at the beginning of the twentieth century "Tarihnama" of Shadi Zhangiruly, have made the analysis. On that there are reasons. Firstly, Zhangiruly Shadi is a descendant of Genghis Khan has been known akin of his time in Central Asia. Well knew shezhire and historical facts about Genghis Khan. In his work indicates a link sources. Second, this work was written before the establishment of Soviet power on the Kazakh land. During the Soviet era images of many historical figures were distorted by in what has political implications. From this point of view in the epos "Tarihnama" Genghis Khan's artistic image is close to the historical reality.

Kenesary worries and increases the interest of scientists up to this day. In the course of this article were studied spiritual heritage of the Kazakh people dedicated Kenesary - historical epics. For many years, the historical epic, as the object of research in folklore, remained outside the attention of historians. Also, in the history of science in the Soviet era historians about the topic of Kenesary was pressured. From this viewpoint the importance of this article is to firstly, the use of verbal historical epics as historical sources, and secondly, the analysis of the personal nature Kenesary Khan by the customer, the study of verbal historical epics. Kazakh people have quite a number of historical epics on the theme Kenesary. This article has been learned about the important work written about Kenesary - historical epic "Kenesary-Nauryzbai" Nysambay zhyrau. Work was carried out comparisons and artistic analysis of the two versions of the epic. Author of the historical epic Nysambay zhyrau contemporary of Kenesary Khan, from beginning to end was started by Kenesary struggle for the emancipation and saw with his own eyes the events as referred in the epic. With respect to the image in the historic epic of Kenesary analysis was conducted on an epic overstatement and the ratio of historical reality. Analyzing the information in the historical epic, determined that Kenesary was an exceptional man with dignity and controversial moments in Khan's politics. Poems about Kenesary Khan - to spread the idea of a struggle on the road to freedom, valuable asset of our national literature 
recreates a beautiful image of the heroes of the people.

The importance of the article - its educational significance. The ability to use the example of great events and great personalities in the education of the present generation, reproduce spiritual strength historical research is an urgent problem. Figures as Genghis Khan, Kenessary Khan put the interests of the people above their personal and devoted their life's journey that purpose. Obviously, the exemplary life of our defenders will educating the next generation to be strong in spirit and look at the history and culture of their people and their country with great respect.

In the learning process can be widely applied research results. Particularly in the main course of faculty of philology, history of the university - can be widely used in training courses History of Kazakh literature, folklore, history of Kazakhstan courses and special elective courses "Intellectual History", "Verbal history", "Source".

Conclusions and results of the research will enlarge the scientific basis of historical sources and will be a kind of contribution to the development of history, historiography, document studies, literary criticism and folklore. It is impossible to cover all aspects of research in that short period of time since the oral history of Kazakhs is extremely versatile and the application of oral history in historical researches has been started very recently. I believe it is a perspective sphere for future researches in literature and history.

It can be said that regardless of which Kazakh literary genre one reads, it is impossible not to encounter representations of Chinggis Khan and Kenesary. Understanding the close links and mutual development of history and literature remains a central task of scholarship.

\section{REFERENCES}

[1] Q. Abdezuly, Tarih Zhane Tagdyr, Almaty: Qazygurt, p. 16, 2004.

[2] N. Kelimbetov, Shadi Akyn, Almaty: Zhazushi, p. 54, 1974.

[3] A. Konyratbayev, Colected Works in Many Volumes, Almaty: MerSal, p. 214,2004

[4] S. Zhangiruly, Institute of Art and Literature, Tarikh-Nama, pp. 31-249.

[5] Kazakhstan. (1998). The National Encyclopedia. Almaty: Kazakh encyclopedia. [Online]. 7. Available: http://kk.wikipedia.org/wiki/

[6] Secret History of the Mongols. History of Nomads between XII-XIII, Almaty: Oner, p. 34, 2009.

[7] B. Bartold, Turkestan during the Mongol Conquests, Moscow, ed.1. p. $139,1963$.

[8] M. Magauin, The Literature of Kazakh Khanate: A Book for Secondary School Students, Almaty: Ana tili, p. 12, 1992.

[9] Z. Qinayatuly, Chinggis Khan, ed. 1. Almaty: Arda, p. 372, 2008.

[10] Kazakh Literature, Encyclopedia, Almaty: Bilik, p. 283, 1999.

[11] N. Zhyrau, "Historical poem kenesary - nauryzbai," Kazakh Historical Epics, vol. 3, pp. 15-44, 1996.

[12] N. Zhyrau, "Samples of the Kyrgyz epic poetry in songs and the lyrical content, arrangements of the Russian language," Song about Kenesary, no. $10-17$, p. $7,1885$.

[13] M. Auezov, About Literature, Almaty: Sanat, p. 46, 1997.

[14] E. Bekmakhanov, Kazakhstan in the 20-40th Years of the Nineteenth Century, Almaty: Sanat, p. 32, 1992.

[15] J. Tlepov, Historicism of Kazakh Poetry, Almaty: Zhazushi, p. 26, 1994.
[16] E. Tursunov, "Historical epics," History of Kazakh Literature, Almaty: Arys, vol. 6, pp. 31-32, 2006.

[17] S. Kaskabasov, "Song and history," The Cradle of Art, Almaty: Ana tili, p. 316, 1992.

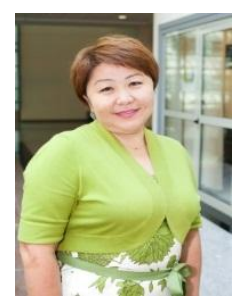

Meiramgul Kussainova was born in 1967 in Central Kazakhstan. She received a bachelor's degree in history and social-humanitarian disciplines from Karaganda State University after Buketov, in 1991. Post-graduate. Almaty state university after Abay, Awarded scientific degree: Candidate of history sciences, 1997. She received a master's degree in International University after Suleiman Demirel, Master of philology, 2009. She received a PhD's degree in International University after Suleiman Demirel, PhD of philology.

She is an associate professor in Kazakh Language, Literature and Culture Department, School of Humanities and Social Sciences at Nazarbayev University.

Currently Meiramgul is teaching history of Kazakhstan, intellectual history, Kazakh culture and Kazakh music history, Kazakh literature for undergraduate students and students of preparatory school.

She had published two monographs, five textbooks, and participated in a number of republic and international conferences. She is currently gathering material for an English-language anthology of primary sources on Kazakh history.

Her research area is problems of in the history of Kazakhs elites under Russian rule in the $19^{\text {th }}$ century and the use of oral epic poetry in the study of $18^{\text {th }}$ and $19^{\text {th }}$-century Kazakh history. Research works are dedicated to issues regarding technology of using oral materials in historical research, comparative analysis of oral and written sources, genre features of historic songs and traditions, analyses of Kenesary Kasymuly images in oral history, recovery of history of Kazakhs by oral materials, oral epic traditions and historic activities, destinies and heritage of graduates of Russian educational institutions, transformation of ideology of Kazakh elites under traditional and imperial politics.

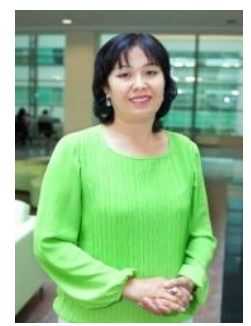

Zhanar Abdigapbarova was born in 1979 in South Kazakhstan. She received a bachelor's degree in Kazakh National University named after Al-Faraby in Almaty in 1997 and obtained a bachelor degree by specialty "Kazakh language and literature" in 2002. Master's degree in Kazakh National University named after Al-Faraby in Almaty, she got a master of philology, 2004. PhD in Kazakh language and literature, 2010.

She is an assistant professor in Kazakh Language, Literature and Culture Department, School of Humanities and Social Sciences at Nazarbayev University.

Currently Zhanar is teaching Kazakh short stories, literature of Alash, Kazakh literature for undergraduate students and students of preparatory school. Her pedagogical philosophy is based on the following principle like by learning literature a student learns to write correctly, to speak correctly and to think creatively. As a Kazakh writer Mukhtar Auezov says: "A person who does not know and respect his language and literature, is not intellectual to a full extent, because despite his education level he will be a citizen with no spiritual and ideological upbringing".

She published more than 30 articles and the monograph entitled "Problems of Kazakh literature in the beginning of XX century". Her research area is problems of Kazakh literature in the beginning of XX century. The monograph discusses the social and political situation in the beginning of the XX century, its influence on literature, creation of religious-educational movement and its role in society. This monograph is actively used in seminars, workshops and lectures in terms of students' research in studying Kazakh Literature at the beginning of the XX century. 